\title{
Discipline of Islamic religious education teachers in the implementation of learning in junior and senior high school students in Sapuka Island
}

\author{
Sultan * \\ Department of Islamic Education, Faculty of Islamic Religion, Cokroaminoto University Makassar, St. Perintis Kemerdekaan \\ Km.11 Tamalanrea, Makassar, South Sulawesi, 90245 Indonesia.
}

International Journal of Science and Research Archive, 2022, 05(01), 086-091

Publication history: Received on 11 January 2022; revised on 14 February 2022; accepted on 16 February 2022

Article DOI: https://doi.org/10.30574/ijsra.2022.5.1.0046

\begin{abstract}
Teacher discipline is one of the main things in education including the discipline of Islamic religious education teachers. Discipline will greatly affect the learning outcomes and achievements of students in the time and future. The purpose of this study is: 1) To find out the discipline of Islamic religious education teachers in Junior High School (SMP) and Senior High School (SMA) in Sapuka Island, 2) To find out an overview of the implementation of learning in junior high school (junior high) and upper school (SMA) students in Sapuka Island. This research is qualitative research with a phenomenological approach. Data collection is done with survey methods with the help of questionnaires with interview techniques. Respondents who were selected using purposive sampling techniques because they are respondents in particular. Respondents consisted of the principal, deputy principal, teacher, supervisor and learners. Data obtained from interview results, field records, and other materials will have meaning after analysis and interpreted using the method of analysis and interpretation of miles and huberman analysis model with steps: data reduction, data display and conclusion. The results of the study were obtained: 1) The level of discipline of Islamic religious teachers is obtained that generally teachers have personal discipline, social discipline, national discipline and time and administrative discipline are quite good (high), although there are still some teachers who are relatively lacking in discipline, especially in time and administrative disciplines, 2) The implementation of Islamic religious education learning is obtained that teachers master learning materials optimally, some teachers apply varied learning methods, but there are still teachers who apply lecture methods, among teachers there are teachers who use learning media, but there are still teachers who have not mastered the use of Information Technology Communication (ITC) based media, and some evaluate learning continuously, but on the other hand there are still teachers who do not master the use of Information Technology Communication (ITC) based media, and some evaluate learning continuously, but on the other hand still There are teachers who still need to be optimized for the implementation of learning evaluations, and all teachers have not implemented the learning model.
\end{abstract}

Keywords: Discipline; Learning process; Achievement; Influence

\section{Introduction}

Islam is a religion that strongly upholds the search for science through education and teaching [1]. Even theologically Allah SWT, directly carry out the process of education and teaching to humans as described in the Qur'an. QS Al-Alaq/96: 1-5 "Read by the name of your God who created, He created man out of a lump of blood. Read, and it is your Lord who is merciful, who teaches (man) through kalam, He teaches man what he does not know".

\footnotetext{
${ }^{*}$ Corresponding author: Sultan

Department of Islamic Education, Faculty of Islamic Religion, Cokroaminoto University Makassar, St. Perintis Kemerdekaan Km.11 Tamalanrea, Makassar, South Sulawesi, 90245 Indonesia.
} 
For the Indonesian nation, religion is an inseparable part of its life, both as an individual being and as a member of society (social creatures). If we look at the reality today, one of the causes of the failure of religious education in Indonesia is due to the lack of orientation, programs, and desire to create a critical, open, and innovative generation.Recognizing the urgency of religion in the life of this nation, national education serves to develop the ability and form the character and civilization of a dignified nation in order to educate the life of the nation, aiming to develop the potential of learners to become human beings who believe and fear God Almighty, noble, healthy, capable, creative, independent, and become democratic and responsible citizens [2]. The purpose of this education is in harmony with the goals of national development even with the teachings of Islam it'self.

Education is a conscious effort and aims to develop human qualities as an activity that is aware of the purpose, so that its implementation is in a continuous process at every type and level of education, all related to an integral education system. Education is essentially the interaction between educators and learners, to achieve educational goals that take place in a particular environment called educational interaction [3]. Teachers are one of the major components in education, including religious teachers. Religious teachers play a role in the formation of islamic religious education in schools.Because the role of religious teachers cannot be replaced by anyone and even anything else, there are human elements that exist in teachers that cannot be replaced by sophisticated machines. Religious teachers must be able to radiate the values of religious teachings, both in the management of the classroom, in teaching and learning activities and in their personal appearance. Religious teachers must also set a good example and example to students. The teacher's task in learning is not limited to the delivery of learning materials, but more than that, teachers must always monitor the behavior of learners, especially during school hours, so that there are no behavioral deviations for indiscipline actions. For this purpose, in order to discipline the teacher must be able to be a guide, example or example, supervisor, and controller of all student behavior.

Discipline must be instilled in every individual, be it teachers or students. The results of research [4] discipline have a real effect on a person's performance. While the results of research [5] mention that a person's performance is not only influenced by discipline but also his duties and placement. While according to [6] that a person's performance is influenced by competence and job satisfaction.Meanwhile[7] that performance is strongly influenced by leadership and job satisfaction. As an teacher, disciplinary factors, duties and placement as teachers, their compatibility, and leadership and satisfaction factors in work often affect their attitudes and actions. All attitudes and behaviors that he does, of course, will be seen and exemplified by his students. If a teacher has an undisciplined attitude then it cannot be blamed if the student also follows the behavior of the undisciplined teacher. As ateacher is required to be able to comply with all the rules that have been imposed at the school and also apply discipline in the learning process. The teacher arrives on time and does not leave the class before the time the lesson is completed is an example of the teacher's discipline. Discipline is expected to develop the achievements of learners well. For this reason, this study becomes very important to know the level of discipline of Islamic religious education teachers in junior and high school.

\section{Material and methods}

\subsection{Type and approach of research}

This type of research is qualitative research. Qualitative research is research used to examine the condition of natural objects, namely something that is what it is, not manipulated by its circumstances and conditions [8].Qualitative research places researchers as key intrusions, data collection techniques are triangulated/combined, data analysis is inductive and research results emphasize meaning rather than generalizations [9]. The approach used in this study is a phenomenological approach [10]. Phenomenological approach is used to express facts, symptoms and events objectively related to the discipline of Islamic religious education teachers in the implementation of learning in junior and senior high school students in Sapuka Island.

\subsection{Time and place}

The research was conducted in August to September 2021, at Junior High School (SMP) and Senior High School (SMA) in Sapuka Island, Liukang Tangaya Subdistrict, Pangkep Regency, South Sulawesi Province.

\subsection{Data Collection Methods}

The data collection method carried out is a survey method with the help of questionnaires with interview techniques. According to [11] the retrieval of research data relies heavily on the purpose and methods of data analysis used in research. The data sources in this study are special respondents, namely those who know and / or are close to the Islamic teacher.The method of determining respondents is used purposive sampling technique. Purposive sampling technique, which is a technique of sampling data sources with certain considerations. Certain considerations in 
question, for example, the person is considered to know the most about something that is expected by the researcher. The samples used as data sources in this study include: principal, deputy principal, teacher, supervision (supervisor) and learners.

\subsection{Data Analysis Methods}

Data obtained from interview results, field records, and other materials will have meaning after analysis and interpreted using methods of analysis and interpretation of data relevant to research needs. In relation to this study, the method of analysis and interpretation of data used by researchers is miles and huberman analysis model with steps: data reduction, presentation of data (data display) and conclusion.

\section{Results and discussion}

\subsection{Discipline of the teacher}

The level of discipline of the teacher in general can be seen from several main indicators, namely; self-discipline, social discipline, national discipline, as well as time and administrative discipline. According to[4] discipline have a real effect on a person's performance. Self-discipline in question is discipline in accordance with the indonesian teacher code of ethics, namely a teacher with pancasila spirit and obedient and obedient to the 1945 constitution and carrying out his duties in accordance with education regulations. The principle of professionalism is that teachers carry out their duties professionally which are also regulated in educational regulations [12]. And the characteristics of Islamic teachers are teachers obedient to Allah and Messenger and behave with good ethics and morals [13].The self-discipline of islamic religious education teachers who begin in himself always practice what he wants to convey before teaching his students in obeying the rules of applying in school, come quickly and not late to school, speak a noble word, dress politely and neatly. Discipline is important for teachers and teachers not only to teach but teachers must also guide students in a good direction to form knowledge and spiritual students [14]. The discipline of islamic education teachers I see quite well expands his mandate in this school not only teaching but also guiding students.In the practice of discipline start from yourself if the teacher is disciplined will have a positive impact on students. Very disciplined in addition to teaching Islam he also early exemplified it in his daily life let alone his home close to school can monitor students inside and outside the school. Teachers of Islamic religious education at Makassar Industrial Technology High School are very disciplined, assertive and attentive to students always give good examples, good advice, good motivation towards students and can control students outside and outside school. Looking polite according to the standards of Islamic fashion values, always present quickly to school and go home according to the schedule of school.

Social discipline is a person's adherence to rules or norms that apply in society. This social discipline, if it is owned by the citizens of society as a whole, will be able to help create a harmonious, harmonious and balanced life in all aspects of life. The school is the place of the teaching and learning process, in which teachers and students and other employees are coordinated by the head who is commonly referred to as the principal.In this case, to achieve the educational goals in the school, teachers play an important role both as educators and as teachers in schools, the back and forth of a school is the responsibility of teachers and other employees supervised and coordinated by a principal. To keep the quality of education maintained and high educational goals will be achieved, teachers as teachers and educators always try and create discipline in all aspects related to the school in which he serves the responsibility.

National discipline in schools must be applied jointly by teachers to realize that the state with a high national nature, so as to avoid differences in ethnicity, race and region. For there is unity and unity in order to achieve the goals of education and teaching. The rules and order that teachers apply in schools aim to unite students with students, teachers with teachers consisting of various tribes and regions. In addition, national discipline aims to strengthen the spirit of pride of the Indonesian nation.

The discipline of the presence of teachers, especially teachers of Islamic religious education, is quite disciplined never too late unless there are urgent things that cannot be left out but there is usually rational notice if the teacher is not willing to attend. Discipline is very disciplined, diligent in teaching and learning, not lazy in teaching and learning, timely in teaching and learning. Teachers are always on time to enter teaching, informing if there are obstacles but that rarely happens.Teachers as participants in education administration, what is meant by teacher discipline in education administration is the participation of teachers in the activeness of preparing educational environment situations. As a system maker and including implementers of education and teaching systems teachers must pay attention to several components that include: The purpose of learning is to instill a number of norms to learners. The subject matter is that the teacher prepares the subject matter.Teaching and learning activities to achieve established learning goals. Method is the way used to address the goals that have been set. Tools are everything that is used to support the teaching and 
learning process. The source of the lesson is everything that is used as teaching material. And evaluation is an activity used to get data about the success of the teaching and learning process.

\subsection{Implementation of learning}

The implementation of Islamic religious education learning in junior and upper secondary school students in Sapuka Island, can be seen from several sub-sections, including; preliminary activities, mastery and development of subject matter, application of learning methods, use of learning media, and assessment of learning outcomes of Islamic religious education. In the preliminary or early learning activities are carried out, namely:First pray continued tadarrus or memorization of the verse about three minutes represented by two learners in each meeting. Second, the perception is by asking questions that relate to the material of previous meetings, so that learners can open memories or memories about past lessons. Third, convey the competencies to be mastered, the benefits of competence to be mastered, conveying the goals to be achieved in the meeting. The fourth identifies the learning readiness of learners. Fifth, give motivation and encouragement to learners to follow the learning.

Mastery of Islamic religious education material is all that is related to the subject matter taught to learners who must be mastered by islamic education teachers. Researcher interviews with learners obtained "I think the teacher mastered the subject matter because every teacher finished discussing gave us the opportunity to ask questions and always receive questions and answer well. If the teacher of Islamic religious education at school I present the subject matter, then ask us (learners) and give us the opportunity to ask. If the teacher of Islamic religious education at school I convey and very good how to explain we are easy to understand. It is also common to explain the lesson even though it is not in the book, but with regard to the subject matter".

Based on the results of the interview showed that Islamic religious education teachers mastered learning materials because in the learning process teachers explained that the subject matter was considered good by learners, and always gave opportunities for learners to ask questions and discuss [15].Learning methods contain the meaning of a way, pattern or strategic step carried out by an Islamic Religious Education teacher to raise the spirit and motivation of learners in following and understanding the series of learning processes according to the subject matter presented, in order to achieve educational goals [16]. Related to the application of learning methods researchers held interviews with the principal. In the formulation of learning methods teachers adjust to the subject matter to be taught and consider the conditions of the ability of students, consideration of time allocation and the state of the school environment [17].

The views of Islamic religious education teachers, principals, deputy principals and learners basically they have almost the same view towards the use and management of learning media used by Islamic religious education teachers. It is important to note by teachers of Islamic religious education, that there is no one medium that is suitable for all learning materials [18]. That is why islamic religious education teachers at Junior and High School in Sapuka choose and use learning media adapted to the subject matter and methods applied. The selection of media in accordance with the level of imagination of learners to be able to understand it. So that from the results of the use of media it grows an intelligent human resource figure and can actualize the meaning of science that he learned.

Assessment of the results of Islamic religious education learning or evaluation of learning to find out the understanding of learners of learning materials, train courage and invite learners to recall the material that has been given. The purpose of evaluation is not only for learners, but aims to evaluate teachers who have been implemented in learning to achieve educational goals. Based on the observation interview, the observation showed that islamic religious education teachers have carried out learning evaluations well starting from the initial evaluation during the learning process, and the evaluation of the end of the semester to measure the ability of learners and the success of teachers in carrying out learning.However, the Covid-19 pandemic factor also has a real influence on the success of teachers in educating their students. Online learning systems cause non-optimal learning to students. The results of [19] research that there are several strategies carried out by rural communities to survive the covid-19 outbreak period, including in the process of teaching and learning in schools. While another factor is the emotional connection factor or closeness between teacher and student. These relationships will greatly impact the level of learning acceptance. The results of research [20] that the influence of relationship patterns formed such as patron-client is very influential on a person's performance.

\section{Conclusion}

The level of discipline of Islamic religious teachers is obtained that generally teachers have personal discipline, social discipline, national discipline and time and administrative discipline are quite good (high), although there are still some teachers who are relatively lacking in discipline, especially in time and administrative disciplines.The implementation of Islamic religious education learning is obtained that teachers master learning materials optimally, some teachers 
apply varied learning methods, but there are still teachers who apply lecture methods, among teachers there are teachers who use learning media, but there are still teachers who have not mastered the use of information technology communication (ITC) based media, and some evaluate learning continuously, but on the other hand there are still teachers who do not master the use of information technology communication (ITC) based media, and some evaluate learning continuously, but on the other hand still There are teachers who still need to be optimized for the implementation of learning evaluation, and all teachers have not implemented the learning model.

\section{Compliance with ethical standards}

\section{Acknowledgments}

Thank you for Dean of Islamic Religion Faculty of Cokroaminoto University Makassar. Thank you to the Head of Sapuka Island and staff for cooperation during the research took place.

\section{References}

[1] Abuddin Nata. Philosophy of Islamic Education, Jakarta: Media Pratama. 2005.

[2] Abuddin Nata. Islamic Perspective on The Pattern of Teacher Relationship with Students, (Study of Sufi Al-Ghazali Thought), First Edition, Jakarta: PT. Raja Grafindo Persada. 2001.

[3] Abuddin Nata. Islamic Perspective on Learning Strategies. First Edition. Jakarta Kencana Prenada Media Group. 2009.

[4] Rahman Abdul., Yusuf Muhammad. Influence of discipline and working period on employee performance at PT Yugier Care Indonesia. International Journal of Science and Research Archive. 2021; 03(02): 123-127.

[5] Rahman Abdul., Yusuf Muhammad. Determinant of placement on the performance of the civil servant apparatus (ASN) in the mare subdistrict of bone regency. Open Access Research Journal of Multidisciplinary Studies. 2021; 02(01): 001-004.

[6] Azikin, Yusuf Muhammad. Influence of competence and job satisfaction on the performance of the state civil apparatus (ASN) in Tonra district of bone regency. International Journal of Science and Research Archive. 2021; 03(02): 118-122.

[7] Idrus., Yusuf Muhammad. The effect of leadership on job satisfaction and employee performance (Case study: Geo space Intimatika Ltd. in Jakarta). International Journal of Science and Research Archive. 2021; 03(02): 128133.

[8] Armai Arif. Introduction to the Science of Islamic Education Methodology. First Edition, Jakarta: Ciputat Pers. 2002.

[9] Yusuf M, Nurhamlin, Y. Setiawan, E.A Supeni, Decision Support System di Era 4.0 Teory \& Aplikasi Tools Analysis. PT. Penerbit IPB Press. 2020; 179.

[10] Burhan Bungin. Methodology of Qualitative Research of Methodological Actualization Towards Contemporary Variant Variety. First Edition, Jakarta: PT. Rajagrafindo Persada. 2010.

[11] Yusuf M, Daris L. Analysis of Research Data; Theory \& Application in Fisheries. PT. IPB Press. Bogor. 2018.

[12] Abdul Haling. Learning and Learning. Second Edition, Makassar: Makassar State University. 2014.

[13] Bahaking Rama. Theory and Implementation of Learning. First Edition; Makassar: Alauddin University Press. 2014.

[14] Cece Wijaya, A Tabrani Rusyam. Basic Teacher Skills in the Teaching and Learning Process, Jakarta: PT. Grafindo. 2004.

[15] Abu Ahmadi, Suro Tri Prasetyo. Teaching and Learning Strategies. First Edition, Bandung: CV. Pustaka Setia. 1997.

[16] Ahmad Sabri. Teaching and Learning Strategies and Micro Teaching. First Edition, Jakarta: Ciputat Pers. 2005.

[17] Azhar Arsyad. Learning Media. Nine Edition, Jakarta: PT. Raja Grafindo Persada. 2007.

[18] Agus Suprijono. Coopertive Leaarning; Paikem Theory and Application. Four Edition; Yogyakarta: Pustaka Pelajar. 2010. 
[19] Gunawan Hendra, Yusuf Muhammad. Strategy of rural community to dealing Covid-19 pandemic in Indonesia (Case Study: Usto Village, Mare Subdistrict in Bone Regency). International Journal of Science and Research Archive. 2021; 04(01): 012-017.

[20] Hasbi, Armin, Sakaria, Sabiq M., Murni A., Yusuf M., Malik. Determinants of 'punggawa-sawi' power relations and capital on the socio-economic household of the fishing community in Paotere Port of Makassar City. AACL Bioflux. 2022; 15(1): 164-173. 